\title{
Prevalence of junk food consumption, overweight/obesity and self-rated health and fitness in high school adolescent girls: a cross sectional study in a deprived area of Qom
}

\author{
Abolfazl Mohammadbeigi ${ }^{1}$, Azadeh Asgarian ${ }^{2}$, Robabeh Ahmadli ${ }^{2}$, Seyedeh Zahra Fara-Shirazi ${ }^{3}$, Esmaeil \\ Moshiri $^{4}$, Hossein Ansari ${ }^{5}$, Salman Khazaei ${ }^{6},{ }^{*}$ Sima Afrashteh $^{7}$
}

Sri Lanka Journal of Child Health, 2019; 48(3): 208-214

\begin{abstract}
Background: Junk food intake is associated with high salt and high caloric intake and is one of the causes of overweight/obesity.
\end{abstract}

Objectives: To assess the prevalence of junk food consumption in snack times and its association with obesity and overweight in high school girl students in a deprived area of Qom.

Method: A cross-sectional study was done in 638 high school girls who were selected using the multistage random sampling method. Overweight/obesity was measured using body mass index (BMI) and a questionnaire was used to ascertain the daily, weekly, monthly, three monthly and occasional junk food consumption. Chi square test and t-test were used to analyse the collected data.

Results: Mean age of participants was $15.77 \pm 0.73$ years (range 15-18 years). The prevalence of underweight and overweight in study subjects was $23.2 \%$ and $11.4 \%$ respectively. BMI was not significantly related to some junk foods $(p>0.05)$. Nevertheless, chocolate/soft drinks were associated

${ }^{1}$ Research Centre Environmental Pollutants,
${ }^{2}$ Neurology and Neuroscience Research Centre,
${ }^{3}$ Student Research Committee, Qom University of
Medical Sciences, Qom, Iran, ${ }^{4}$ Faculty of
Medicine, Arak University of Medical Sciences,
Arak, Iran, ${ }^{5}$ Health Promotion Research Centre,
Department of Epidemiology and Biostatistics,
Zahedan University of Medical Sciences, Zahedan,
Iran, ${ }^{6}$ Department of Epidemiology, School of
Public Health, Hamadan University of Medical
Sciences, Hamadan, Iran, ${ }^{7}$ Msc of Epidemiology,
Bushehr University of Medical Sciences, Bushehr,
Iran
*Correspondence: sima.afrashte3@gmail.com
iD orcid.org/0000-0002-4276-2084
(Received on 22 July 2018: Accepted after revision

(Received on 22 July 2018: Accepted after revision on 28 September 2018)

The authors declare that there are no conflicts of interest

Funded by Qom University of Medical Sciences, Iran

Open Access Article published under the Creative

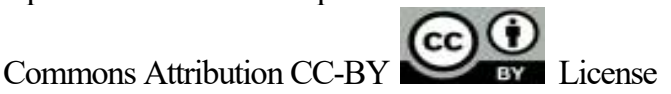

with higher prevalence of underweight (75.8\%) compared to overweight/obesity (57.6\%).

Conclusions: Junk food consumption prevalence was high among the studied population of high school girls in a deprived area of Qom. There was no significant association between junk food consumption and BMI in this study population.

DOI: http://dx.doi.org/10.4038/sljch.v48i3.8754

(Keywords: Junk foods, girls, overweight, obesity, Qom)

\section{Introduction}

Prevalence of obesity is increasing globally ${ }^{1}$. According to the World Health Organisation (WHO) more than 300 million children 5-19 old were overweight or obese in $2016^{2}$. Global studies show an increased prevalence of overweight and obesity in children and adolescents ${ }^{3,4}$. A systematic review in children under 18 years of age in Iran found a prevalence of overweight and obesity of 5.013.5 and 3.2-11.9 respectively ${ }^{1,5}$. Obesity and overweight have a close relationship with diabetes, heart disease, malignancy, asthma, low back pain and depression ${ }^{6}$. Lack of physical activity, lifestyle changes, prolonged television viewing, playing computer games, as well as nutritional factors, such as consumption of fast food / junk food, consumption of calorie dense food, and a family history of obesity are the main causes of obesity and overweight in adolescent girls ${ }^{7,8}$. Low-nutrition high-energy food are known as junk food. Junk food has high energy content that reduces appetite, reduces the chances of feeding with more nutritious foods, and most importantly, causes diseases such as obesity, diabetes and hypertension at an older age $^{9,10}$. Availability, low price, television advertising, diversity, and attractiveness of the package and lack of parental awareness are the main causes of students' tendency to consume junk food $^{11}$. However, the lifestyle in students, especially high school girls, is not appropriate due to consumption of low-value foods and the trend of obesity and overweight prevalence among adolescents is increasing ${ }^{1,11}$.

\section{Objectives}

To assess the prevalence of junk food consumption 
in snack times and its association with obesity and overweight in a deprived area of Qom.

\section{Method}

This cross-sectional study was performed on high school girl students in Qom in spring 2017. Random multi-stage sampling was used. First, one of the deprived areas was selected from 4 different educational areas in Qom and then 16 different high schools were selected as stratum based on different majors and governmental versus non-governmental schools. Finally, in each school, 40 students were selected by simple random sampling.

A pilot test was conducted on 50 students to confirm the reliability of the questionnaire and Cronbach's alpha value was computed as 0.871 . The questionnaire used was based on food frequency and included demographic characteristics including age, marital status and family income. Sixteen different questions were asked to assess the consumption of junk foods, homemade sandwiches and nuts. Sample size calculation was based on the junk food consumption in previous studies and alpha error was 0.05 . Therefore, minimum sample size calculated was 580 subjects. We assessed 640 high school girls and 638 ones completed the questionnaires.

Part A of questionnaire assessed demographic information such as study field, age, weight, height, waist circumference, parental educational level, parental occupation, economic and cultural status, self-reported health (SRH) and self-reported fitness (SRF). Part B included questions about consumption of snacks, including puff, chips, biscuits, cakes, chocolates, industrial juices, sausages, home sandwich and nuts. Consumption frequency for junk foods was categorized as daily, weekly, monthly, 3 monthly and occasional options. In addition, the availability of each of these snacks was asked at the school buffet. Moreover, SRH and SRF were assessed by a 5 point Likert Scale as these questions. How you evaluate your general health and fitness? That varied the responses from very good: 5 , good: 4 , moderate: 3 , weak: 2 and very weak: 1 .

After obtaining the necessary coordination and obtaining permission from the ethical committee of Qom University of Medical Sciences, the research team was referred to the selected schools and the questionnaire distributed among eligible subjects after taking informed consent. Statistical analyses were performed using the SPSS software. The prevalence rate of overweight/obesity, junk foods consumption and SRH and SRF were computed using descriptive statistics. The qualitative variables were reported as number and percentage and quantitative variables and mean and standard deviation. The analysis of categorical variables was performed using the person Chi square test. $\mathrm{p}<0.05$ was considered significant.

\section{Results}

The demographic characteristics of studied high school girls in Quom city in 2017 are shown in Table 1. The response rate in the current study was $99.7 \%$ $(638 / 640)$. The age range of participants was $15-18$ years. Based on WHO classification the prevalence of underweight and over weight in study subjects was $23.2 \%$ (120 girls) and $11.4 \%$ (59 girls) respectively. However, 65.4\% (338 girls) had normal BMI. Asthma (0.6\%), hypothyroidism $(0.6 \%)$ and heart problems $(0.5 \%)$ were the most common chronic diseases in studied participants.

Table 1

Demographic characteristics of study population

\begin{tabular}{|c|c|}
\hline Qualitative Variable & Number (\%) \\
\hline $\begin{array}{l}\text { Educational year } \\
\text { Tenth } \\
\text { Eleventh }\end{array}$ & $\begin{array}{l}568(88.9) \\
71(11.1)\end{array}$ \\
\hline $\begin{array}{l}\text { Marital status } \\
\text { Single } \\
\text { Married }\end{array}$ & $\begin{array}{l}616(96.4) \\
23(03.6)\end{array}$ \\
\hline $\begin{array}{l}\text { Major } \\
\text { Experimental sciences } \\
\text { Human sciences } \\
\text { Mathematical/Skill sciences }\end{array}$ & $\begin{array}{l}246(38.5) \\
175(27.4) \\
218(34.1)\end{array}$ \\
\hline $\begin{array}{l}\text { Mother's job } \\
\text { Staff } \\
\text { Homemaker } \\
\text { Other }\end{array}$ & $\begin{array}{c}31(04.9) \\
574(90.4) \\
30(04.7) \\
\end{array}$ \\
\hline $\begin{array}{l}\text { Mother's education } \\
\text { Illiterate } \\
\text { Elementary } \\
\text { High school } \\
\text { College }\end{array}$ & $\begin{array}{l}105(16.5) \\
290(45.7) \\
168(26.5) \\
72(11.3)\end{array}$ \\
\hline $\begin{array}{l}\text { Father's education } \\
\text { Illiterate } \\
\text { Elementary } \\
\text { High school } \\
\text { College }\end{array}$ & $\begin{array}{l}50(08.0) \\
238(38.1) \\
223(35.7) \\
114(18.2)\end{array}$ \\
\hline $\begin{array}{l}\text { Income level per month }(\$) \\
249 \text { or less } \\
250-499 \\
500-750 \\
750 \text { or more }\end{array}$ & $\begin{array}{l}312(53.4) \\
144(24.7) \\
64(11.0) \\
64(11.0)\end{array}$ \\
\hline Quantitative Variable & Mean (SD) \\
\hline Age (years) & $15.77(0.73)$ \\
\hline BMI $\left(\mathrm{kg} / \mathrm{m}^{2}\right)$ & $20.85(03.29)$ \\
\hline Weight (kg) & $54.33(08.95)$ \\
\hline Height $(\mathrm{cm})$ & $161.86(07.29)$ \\
\hline $\begin{array}{l}\text { Moderate physical activity } \\
\text { (minutes) }\end{array}$ & $25.13(26.93)$ \\
\hline $\begin{array}{l}\text { Severe physical activity } \\
\text { (minutes) }\end{array}$ & $12.29(19.42)$ \\
\hline
\end{tabular}

The results in table 2 and Figure 1 showed that the consumption prevalence in some junk foods was very high. 
Table 2: Prevalence of junk food consumption in studied population

\begin{tabular}{|c|c|c|c|c|c|c|c|}
\hline & None & Every day & $\begin{array}{l}\text { Every } \\
\text { week }\end{array}$ & $\begin{array}{l}\text { Every } \\
\text { month }\end{array}$ & $\begin{array}{l}\text { Every Season } \\
\text { (Sometimes) }\end{array}$ & $\begin{array}{c}\text { Previous } \\
\text { month }\end{array}$ & $\mathrm{CI}$ \\
\hline Biscuits & $94(14.7)$ & $231(36.2)$ & $180(28.2)$ & $38(5.9)$ & $96(15)$ & $449(70.3)$ & $(0.687-0.718)$ \\
\hline Chocolate/Soft drinks & $189(29.6)$ & $55(8.6)$ & $168(26.3)$ & $93(14.6)$ & $134(20.9)$ & $316(49.5)$ & $(0.476-0.513)$ \\
\hline Puff (Poffak) & $146(22.8)$ & $57(8.9)$ & $195(30.5)$ & $86(13.5)$ & $155(24.2)$ & $338(52.9)$ & $(0.510-0.547)$ \\
\hline Chips & $147(23.0)$ & $55(8.6)$ & $188(29.4)$ & $85(13.3)$ & $164(25.7)$ & $328(51.3)$ & $(0.494-0.531)$ \\
\hline Popcorn & $132(20.7)$ & $69(10.8)$ & $174(27.2)$ & $91(14.2)$ & $173(27.1)$ & $334(52.3)$ & $(0.504-0.541)$ \\
\hline Fruit leather//Indian stamp & $133(20.8)$ & $121(18.9)$ & $178(27.9)$ & $79(12.4)$ & $128(20)$ & $378(59.2)$ & $(0.573-0.610)$ \\
\hline Ice Cream & $155(24.3)$ & $76(11.9)$ & $148(23.2)$ & $86(13.5)$ & $174(27.2)$ & $310(48.5)$ & $(0.466-0.503)$ \\
\hline Candy/ Chewing Gum & $146(22.8)$ & $123(19.2)$ & $150(23.5)$ & $66(10.3)$ & $154(24.1)$ & $339(53.1)$ & $(0.512-0.549)$ \\
\hline Industrial Sandwich & $160(25.0)$ & $51(8.0)$ & $142(22.2)$ & $110(17.2)$ & $176(27.5)$ & $303(47.4)$ & $(0.455-0.492)$ \\
\hline Industrial Juice & $145(22.7)$ & $58(9.1)$ & $154(24.1)$ & $97(15.2)$ & $185(29)$ & $309(48.4)$ & $(0.465-0.502)$ \\
\hline Industrial Nuts & $142(22.2)$ & $51(8.0)$ & $146(22.8)$ & $99(15.5)$ & $201(31.5)$ & $296(46.3)$ & $(0.444-0.481)$ \\
\hline Sausage Sandwich & $326(51.0)$ & $13(2.0)$ & $47(7.4)$ & $60(9.4)$ & $147(30.2)$ & $120(18.8)$ & $(0.176-0.199)$ \\
\hline Milk/Chocolate Milk & $93(14.6)$ & $185(29.0)$ & $207(32.4)$ & $55(8.6)$ & $99(3.5)$ & $447(70)$ & $(0.684-0.715)$ \\
\hline Homemade Sandwich & $106(16.6)$ & $132(20.7)$ & $151(23.6)$ & $112(17.5)$ & $138(21.6)$ & $395(61.8)$ & $(0.600-0.635)$ \\
\hline Homemade Nuts & $96(15.0)$ & $143(22.4)$ & $148(23.2)$ & $103(16.1)$ & $149(23.3)$ & $394(61.7)$ & $0.599-0.634)$ \\
\hline
\end{tabular}

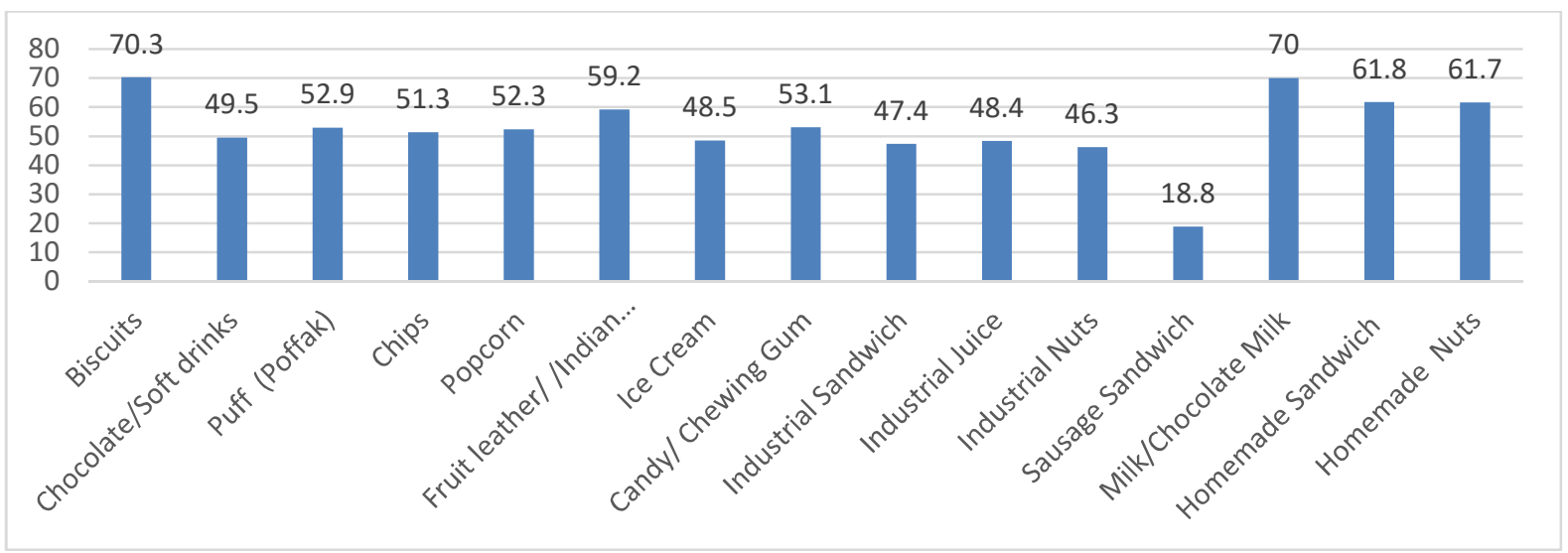

Figure 1: Prevalence of consumption of junk foods in studied subject previous month

Based on the results the prevalence of consumption of biscuits was $70.3 \%$ (CI $(0.687-0.718)$ ) in the previous month. However, less than $25 \%$ of studied girl students in high schools did not consume puff, chips, popcorn, fruit leather/Indian stamp, ice cream, candy/chewing gum, industrial sandwich, industrial juice and nuts. However, the prevalence of sausage sandwich consumption was $18.8 \%$ (CI $(0.176-0.199))$ and $61.8 \%$ (CI $(0.600-0.635))$ consumed homemade sandwich in the previous month. In addition, 61.7\% (CI (0.599 - 0.634)) reported that they consumed homemade nuts in the last month.

According to Chi Square results in table 3, there was no significant association of BMI with consumption of biscuits, puff, chips, popcorn, fruit leather/Indian stamp, ice cream, candy/ chewing gum, industrial sandwich, industrial juice, industrial nuts, sausage sandwich, milk/chocolate milk and homemade nuts $(p>0.05)$. Nevertheless, chocolate/soft drinks were associated by higher prevalence of underweight $(75.8 \%)$ (CI (0.744- 0.771)) compared to lower prevalence of overweight/obesity (57.6\%) (CI (0.557 - 0.594). Moreover, homemade sandwich consumption was associated with higher overweight/obesity (96.6\%) (CI (0.963 - 0.968)) compared to normal weight girls (79.3\%) (CI 0.780 $-0.805)$.

Figure 2 shows that the most portions of subjects have good and very good SRH and Self Rated Fitness (SRF). 
Table 3: Relationship between junk foods consumption and general obesity based on BMI

\begin{tabular}{|l|c|c|c|c|c|c|}
\hline & Underweight & Normal & Overweight/Obesity & Total & CI & $p$ value \\
\hline Biscuits & $104(86.7)$ & $286(84.6)$ & $50(84.7)$ & $440(85.1)$ & $(0.841-0.860)$ & 0.860 \\
\hline Chocolate/Soft drinks & $91(75.8)$ & $214(63.3)$ & $34(57.6)$ & $339(65.6)$ & $(0.639-0.672)$ & 0.018 \\
\hline Puff (Poffak) & $88(73.3)$ & $254(75.1)$ & $52(88.1)$ & $394(76.2)$ & $(0.748-0.775)$ & 0.068 \\
\hline Chips & $93(77.5)$ & $250(74.0)$ & $50(84.7)$ & $393(76.0)$ & $(0.746-0.773)$ & 0.183 \\
\hline Popcorn & $99(82.5)$ & $266(78.7)$ & $47(79.7)$ & $412(79.7)$ & $(0.784-0.809)$ & 0.673 \\
\hline Fruit leather//Indian stamp & $96(80.0)$ & $261(77.2)$ & $49(83.1)$ & $406(78.5)$ & $(0.772-0.797)$ & 0.545 \\
\hline Ice Cream & $87(72.5)$ & $248(73.4)$ & $50(84.7)$ & $385(74.5)$ & $(0.730-0.759)$ & 0.154 \\
\hline Candy/ Chewing Gum & $96(80)$ & $274(73.1)$ & $49(83.1)$ & $392(75.8)$ & $(0.744-0.771)$ & 0.122 \\
\hline Industrial Sandwich & $90(75.0)$ & $246(72.8)$ & $49(83.1)$ & $385(74.5)$ & $(0.730-0.759)$ & 0.245 \\
\hline Industrial Juice & $95(79.2)$ & $247(73.1)$ & $48(81.4)$ & $390(75.4)$ & $(0.740-0.767)$ & 0.220 \\
\hline Industrial Nuts & $95(79.2)$ & $255(75.4)$ & $50(84.7)$ & $400(77.4)$ & $(0.760-0.787)$ & 0.250 \\
\hline Sausage Sandwich & $62(51.7)$ & $158(46.7)$ & $28(47.5)$ & $248(48.0)$ & $(0.461-0.498)$ & 0.648 \\
\hline Milk/Chocolate Milk & $102(85.0)$ & $285(84.3)$ & $54(91.5)$ & $441(85.3)$ & $(0.843-0.862)$ & 0.351 \\
\hline Homemade Sandwich & $104(86.7)$ & $268(79.3)$ & $57(96.6)$ & $429(83.0)$ & $(0.819-0.840)$ & 0.002 \\
\hline Homemade Nuts & $104(86.7)$ & $286(84.6)$ & $53(89.8)$ & $443(85.7)$ & $(0.847-0.866)$ & 0.539 \\
\hline
\end{tabular}

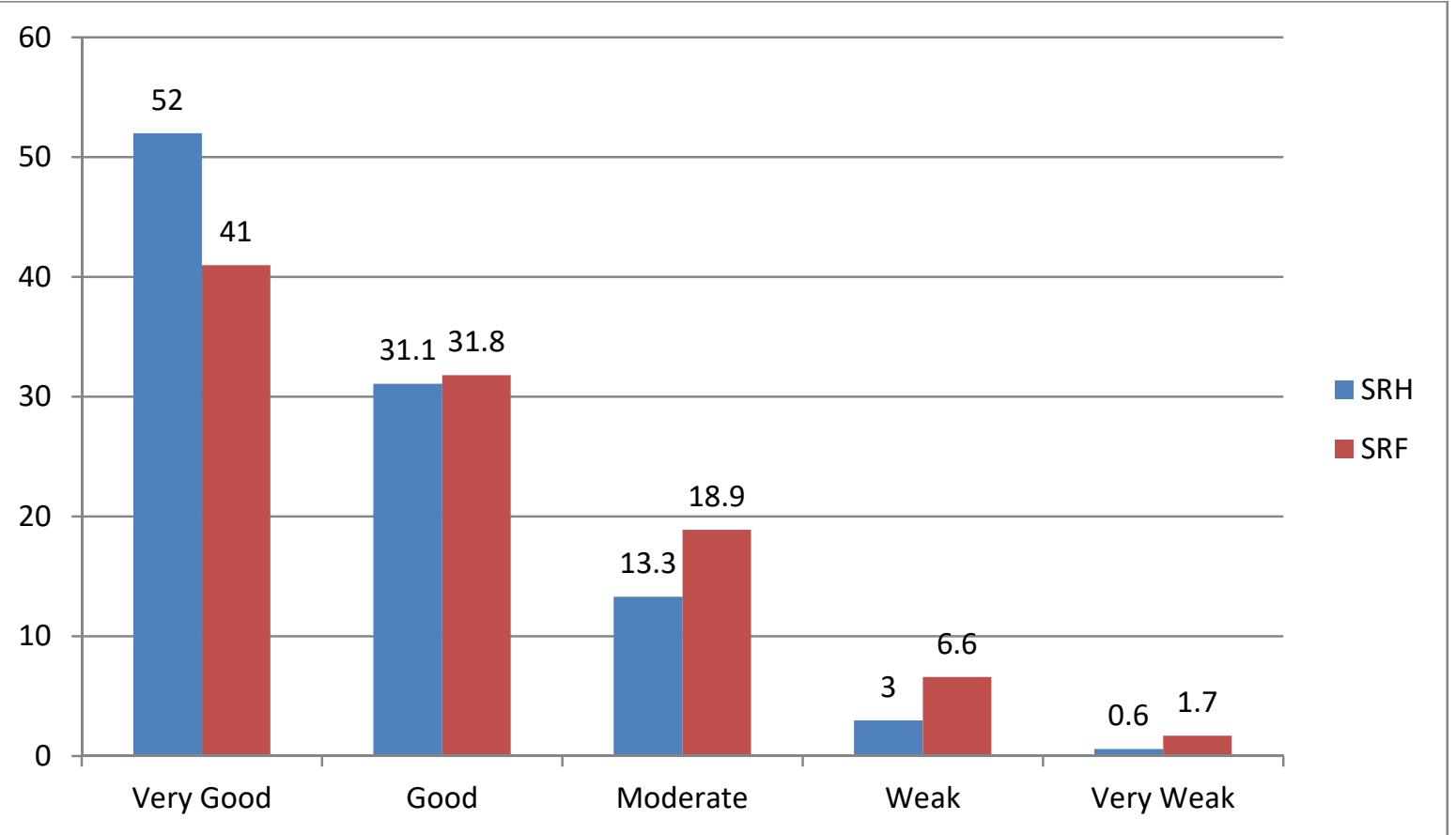

Figure 2: Prevalence of self-reported health and self-reported fitness in studied girls

\section{Discussion}

Based on our results, $65.4 \%$ of studied high school girls were of normal BMI based on WHO BMI classification, $23.2 \%$ had overweight/obesity and $11.4 \%$ were underweight. The obesity and underweight prevalence in our study population is considerable as these girls are in pubertal age and are of marriageable age. Hemmati et al in a study in Urmia showed that the prevalence of overweight and obesity in high school girls was $20.5 \%$ and $10.9 \%$ respectively which is consistent with the results of our study ${ }^{12}$. Bibiloni et al. in a review study on adolescents all over the world showed that, the prevalence of overweight and obesity is high ${ }^{13}$. Studies showed that differences in socioeconomic status, differences in individual, environmental, access to health care, beliefs and lifestyles are related to obesity/overweight ${ }^{14-16}$.
The present study showed that the consumption of sausage and home-made sandwiches is high among girls. According to one study in Iran, sausages are one of the favourite foods of Iranian people ${ }^{17}$. Our results were compared with other studies and we concluded that there was a higher prevalence of obesity among girls ${ }^{18,19}$. However, high prevalence of junk food consumption and low health literacy in health workers and families and differences in lifestyle among girls compared to other age-sex groups could cause a normal BMI rather than a high BMJ.

The prevalence of junk food consumption in high school girls in Qom was high. Almost 70.3\% and $61.8 \%$ of girls consumed biscuits and home sandwiches in the last month. Furthermore, less than $25 \%$ did not consume chips, puffs, popcorns, fruit leather/ /Indian stamp, ice cream, and other junk foods showing the high prevalence of junk food 
consumption in this population that are in pubertal age $^{14,20}$. Results of other studies showed that fast food intake is associated with high salt and high caloric intake, fat and food poverty ${ }^{15,21}$. Moreover, it is one of the most important causes of overweight/obesity, cardiovascular disease, metabolic syndrome and violent behaviour ${ }^{22-24}$.

Our findings indicate that there is no meaningful relationship between junk foods and BMI. The results of our study have been accordance with previous studies on the prevalence of junk foods and fast food consumption ${ }^{23,25}$. A study by Arif Habib et al. showed no significant relationship between fast food consumption and BMI, which is similar and consistent with our results ${ }^{26}$. Nevertheless, other studies have shown that with increasing consumption of fast food and junk foods, BMI also increases ${ }^{10,27}$. However, fast food consumption is associated with high energy consumption and low dietary quality, as a result of the increase in $\mathrm{BMI}^{28}$.

Our findings indicate that a high percentage of the studied girls have reported good and very good SRH and SRF. According to the other studies low SRH is associated with different cardiovascular diseases, visual impairment, psychological and mental disorders $^{29,30}$. Philips and colleagues showed that people with low SRH and SRF are likely to die earlier than people with good $\mathrm{SRH}^{31}$.

This cross-sectional study was unable to explain the causal relationship between independent variables and junk foods. However, girls who consumed homemade sandwich have higher BMI and the obesity/overweight was not related to puff, chips, popcorn, fruit leather/Indian stamp, ice cream, candy/ chewing gum, industrial sandwich, juice and nuts. This inverse phenomenon in our study could relate to the food size of junk foods such as puff, chips, popcorn or other industrial foods ${ }^{32}$. It is demonstrated that industrial foods are absorbent and the consumer has false fullness after eating these junk foods ${ }^{33}$. Moreover, adolescents are more interested in eating these junk foods and most times they have no desire to eat homemade foods. Consumption of diet high in sugar, salt and calorie content in adolescents can lead to early cardiovascular diseases. Therefore, intervention programmes to prevent junk foods consumption in students is essential

\section{Conclusions}

Junk food consumption prevalence was high among the studied population of high school girls in a deprived area of Qom. There was no significant association between junk food consumption and BMI in this study population.

\section{References}

1. Jafari-Adli S, Jouyandeh Z, Qorbani M, Soroush A, Larijani B, Hasani-Ranjbar S. Prevalence of obesity and overweight in adults and children in Iran; a systematic review. Journal of Diabetes \& Metabolic Disorders 2014; 13(1):121. https://doi.org/10.1186/s40200-014-01212

PMid: 25610814 PMCid: PMC4301060

2. World Health Organization. Fact sheet on obesity and overweight 2017. Available from:

http:/www.who.int/mediacentre/factsheet s/fs311/en

3. Fryar CD, Carroll MD, Ogden C. Prevalence of overweight and obesity among children and adolescents aged 2-19 years: United States, 1963-1965 Through 2013-2014. Health E-Stats. 2016.

4. Petribú MdMV, Tassitano RM, Nascimento WMFd, Santos EMC, Cabral PC. Factors associated with overweight and obesity among public high school students of the city of Caruaru, Northeast Brazil. Revista Paulista de Pediatria 2011;29(4):536-45.

5. Zeinab J, Gholamreza G, Mehdi Y, Mahmood T, Korush J. Factors related to reduction in the consumption of fast food: application of the theory-based approaches. Journal of Public Health Research 2017; 6(2).

PMid: 29071252 PMCid: PMC5641655

6. Kearns K, Dee A, Fitzgerald AP, Doherty E, Perry IJ. Chronic disease burden associated with overweight and obesity in Ireland: the effects of a small BMI reduction at population level. BMC Public Health 2014;14(1):143.

https://doi.org/10.1186/1471-2458-14-143 PMid: 24512151 PMCid: PMC3929131

7. Mistry SK, Puthussery S. Risk factors of overweight and obesity in childhood and adolescence in South Asian countries: a systematic review of the evidence. Public Health 2015; 129(3):200-9.

https://doi.org/10.1016/j.puhe.2014.12.00 4

PMid: 25746156 
8. Aghapour B, Rashidi A, Dorosti-Motlagh A, Mehrabi Y. The association between major dietary patterns and overweight or obesity among Iranian adolescent girls. Iranian Journal of Nutrition Sciences \& Food Technology 2013; 7(5):289-99.

9. Dehdari T, Chegeni M, Dehdari L. Application Planned Behavior in theory predicting Junk Food Consumption among Female Students. Preventive Care in Nursing and Midwifery 2013; 2(2): 18-24.

10. Payab M, Kelishadi R, Qorbani M, Motlagh ME, Ranjbar SH, Ardalan G, et al. Association of junk food consumption with high blood pressure and obesity in Iranian children and adolescents: the CASPIANIV Study. Journal of Pediatrics (Rio J) 2014; 35(9):582-90.

11. Damari B, Riazi-Isfahani S, Hajian M, Rezazadeh A. Assessment of the situation and the cause of junk food consumption in Iran and recommendation of interventions for reducing its consumption. Community Health 2016; 2(3):193-204.

12. Pak H, Saeidlou N, Kousehlou Z, Orujlou S. Prevalence of general and abdominal obesity, overweight among high school girls in Urmia. J Urmia Nurs Midwifery Fac. 2016; 14(9):802-10.

13. Bibiloni MdM, Pons A, Tur JA. Prevalence of overweight and obesity in adolescents: a systematic review. ISRN obesity. 2013; 2013.

14. Talaie-Zanjani A, Faraji F, Rafie M, Mohammadbeigi A. A comparative study of nutritional status and foodstuffs in adolescent girls in Iran. Annals of Medical and Health Sciences Research 2014; 4(1):38.

https://doi.org/10.4103/2141-9248.126606

PMid: 24669328 PMCid: PMC3952294

15. Eshrati B, Hasanzadeh J, Beigi AM. Calculation of population atributable burden of excess weight and obesity to non-contagious diseases in Markazi provience of Iran. Koomesh 2010; 11(2):83-90.

16. Ahmadi A, Ershad M, Givzadeh H, Mohammad-Beigi A. General physicians' knowledge about nutrition in Shiraz, Iran. Pakistan Journal of Biological Sciences 2009;12(13):981-5. https://doi.org/10.3923/pjbs.2009.981.985 PMid: 19817126

17. Asgary S, Nazari B, Sarrafzadegan N, Parkhideh S, Saberi S, Esmaillzadeh A, et al. Evaluation of fatty acid content of some Iranian fast foods with emphasis on transfatty acids. Asia Pacific Journal of Clinical Nutrition 2009; 18(2):187-92.

PMid: 19713177

18. Taheri F, Chahkandi T, Kazemi T, Bijari B. Prevalence of obesity and overweight among adolescents of Birjand, east of Iran. Iranian Journal of Diabetes \& Obesity 2014; 6(4).

19. Zar A, Mohammad AA. Prevalence of obesity and overweight among female students of Shiraz University of Medical Sciences and its association with physical fitness factors. Community Health 2017; 4(2):79-89.

20. Mohammadbeigi A, Anbari Z, Motafakerian H, Mohammadsalehi N, Ghaderi E, Ansari H. The training effectiveness of prevention disability package in High School Girls; a community intervention trial. International Journal of Pediatrics 2016; 4(11):3907-16.

21. Ahmadi A, Mosallaei Z, Moazen M, Mohammadbeigi A, Amin-Lari F. Nutrient intake and growth indices for children at Kindergartens in Shiraz, Iran. Journal of the Pakistan Medical Association 2014; 64(3):316-21.

PMid:24864607

22. Rouhani MH, Mirseifinezhad M, Omrani $\mathrm{N}$, Esmaillzadeh A, Azadbakht L. Fast food consumption, quality of diet, and obesity among Isfahanian adolescent girls. Journal of Obesity 2012;2012.

23. Zahedi H, Kelishadi R, Heshmat R, Motlagh ME, Ranjbar SH, Ardalan G, et al. Association between junk food consumption and mental health in a national sample of Iranian children and adolescents: the CASPIAN-IV study. Nutrition 2014; 30(11):1391-7. https://doi.org/10.1016/j.nut.2014.04.014 PMid: 25280418

24. Asghari G, Yuzbashian E, Mirmiran P, Mahmoodi B, Azizi F. Fast food intake increases the incidence of metabolic syndrome in children and adolescents: 
Tehran lipid and glucose study. PloS one 2015; 10(10): e0139641.

https://doi.org/10.1371/journal.pone.0139

641

PMid: 26447855 PMCid :PMC4598125

25. Yarmohammadi P, Sharifirad GR, Azadbakht L, Yarmohammadi P, Rahaei Z, Bahrevar V, et al. The Association between Socio-Demographic Charactristics and Fast Food Consumption withinHigh School Students in Isfahan, Iran. Journal of Community Health Research 2015; 4(3): 194-202.

26. Habib A, Al Alyani M, Hussain I. Prevalence, Determinants and Consequences of Fast-Food Consumption among college students in Abha-Aseir. IJSRR 2016; 5(3):35-46.

27. Braithwaite I, Stewart AW, Hancox RJ, Beasley R, Murphy R, Mitchell EA, et al. Fast-food consumption and body mass index in children and adolescents: an international cross-sectional study. $B M J$ open 2014; 4(12): 0005813.

https://doi.org/10.1136/bmjopen-2014005813

PMid:25488096 PMCid:PMC4265088

28. Schröder H, Fïto M, Covas MI. Association of fast food consumption with energy intake, diet quality, body mass index and the risk of obesity in a representative Mediterranean population. British Journal of Nutrition 2007; 98(6):1274-80. https://doi.org/10.1017/S00071145077814 36

PMid: 17625027

29. Wu S, Wang R, Zhao Y, Ma X, Wu M, Yan $\mathrm{X}$, et al. The relationship between selfrated health and objective health status: a population-based study. BMC Public Health 2013; 13(1):320.

https://doi.org/10.1186/1471-2458-13-320

PMid: 23570559 PMCid: PMC3637052
30. Mohammadbeigi A, Valizadeh F, Mirshojaee SR, Ahmadli R, Mokhtari M, Ghaderi E, et al. Self-rated health and internet addiction in Iranian medical sciences students; prevalence, risk factors and complications. International Journal of Biomedical Science 2016; 12(2):65. PMid:27493592 PMCid:PMC4947091

31. Phillips AC, Der G, Carroll D. Selfreported health, self-reported fitness, and all-cause mortality: Prospective cohort study. British Journal of Health Psychology 2010; 15(2):337-46.

PMid: 27493592 PMCid: PMC4947091

32. Spanos S, Kenda AS, Vartanian LR. Can serving-size labels reduce the portion-size effect? A pilot study. Eating Behaviors 2015;16:40-2.

https://doi.org/10.1016/j.eatbeh.2014.10.0 07

PMid:25464065

33. Balantekin KN, Birch LL, Savage JS. Patterns of weight-control behavior among 15 year old girls. International Journal of Eating Disorders 2015; 48(6):589-600. https://doi.org/10.1002/eat.22426 PMid: 26284953 PMCid: PMC4542016 